\title{
SELECTED ASPECTS OF PRACTICAL PROJECTS FOR PROPERTY DELIMITATION AND RESUMPTION OF BOUNDARY MARKS, IN VIEW OF THE CURRENT LEGISLATION IN POLAND
}

\author{
Paweł Kotlarz
}

\begin{abstract}
Summary
The aim of this publication is to present, discuss and compare two geodetic-legal procedures in the scope of drawing up a survey report (basic trig data) on two particular geodetic tasks, namely the delimitation (demarcation) of a real estate property, and the resumption (restoration) of boundary marks. The analyses were carried out, based on the current applicable legal acts and relevant implementing rules regarding the surveying activities in question and on the basis of geodetic basic trig data surveys, accepted by the State Geodetic and Cartographic Documentation Centre. The publication presents selected aspects of the discussed works from the point of view of geodetic practice in the field. The author indicates the responsibilities of the authorized (certified) surveyor, and the surveyor's role in these two different geodesic procedures. The effect of the study is to point to the main differences between the two procedures, the effects of which - both in the field and on the map - are similar. The analysis shows the varied level of difficulty of the discussed surveying tasks in the context of formal and legal stipulations currently existing in Poland. Due to the nature of the subject of this study, the conclusions are of local (Poland-specific) nature, without reference to global solutions.
\end{abstract}

\section{Keywords}

delimitation of real estate property resumption of boundary marks • authorized surveyor • geodetic-legal activities

\section{Introduction}

The delimitation of real estate property and the resumption of boundary marks are geodetic activities of varying difficulty. The analysis of their scope and the role of the authorized surveyor in the course of performing these tasks have been described, inter alia, by Hycner and Wiśniewska [2013]. Although the resumption of boundary marks is a relatively simple task from the point of view of the surveyor's tasks, then the procedure of real estate property delimitation can often pose a number of difficulties. This view is confirmed both by the analysis of available literature and the professional experience 
of the author of this publication. The definitions of these two surveying activities are included in the Geodetic and Cartographic Law [Ustawa 1989], in which Article 29 clause 1 says that "The delimitation of real estate property is aimed at establishing the course of its boundaries by defining the location of points and boundary lines, fixing these points with boundary marks in the land, and drafting relevant documents", whereas in accordance with Article 39 clause 1 of the Law "Previously established, shifted, damaged or destroyed boundary marks may be reinstated without conducting delimitation proceedings, provided that there exist documents that facilitate the determination of their original location. However, if a dispute arises as to the position of these marks, the parties may ask the court to resolve the matter." It is worth noting the fact that boundary marks may in the future be subject to resumption based on delimitation procedure, but never the other way around. Another major difference between the two geodetic procedures results from the fact that the delimitation is an administrative procedure, and as such, it is carried out by the local governors (or city mayors). Delimitation procedures are carried out ex officio, or at the request of an interested party.

The most important issue related to both the real estate property delimitation and the resumption of boundary marks is the definition of the object for which surveying activities are carried out, that is the real estate property, and the of boundary marks as such. The term "real estate property" is defined in the Civil Code [Ustawa 1964] Article 46 clause 1 as follows: "Real estate properties are parts of the earth's surface being separate objects of ownership (land) as well as buildings permanently attached to the land, or parts of such buildings, provided that they constitute a separate object from the land under specific provisions". Real estate can be divided into three types. These include land properties, buildings, and premises. The delimitation procedure usually concerns land properties. Information about real estate properties and their owners is collected and stored in public registers. In Poland, we distinguish two registers that are updated on a continuous basis. Without their existence, real estate management would be impossible. These registers are: the Land and Mortgage Register, and the Land and Building Records, also known as Real Estate Cadastre.

The delimitation of a real estate property is a process that leads to the ordering of the legal status of the location of real estate boundaries in the field, and thus to the updating or determining the coordinates of boundary points. In addition, this process also leads to the preservation of boundary marks in the land. The delimitation of real estate, and thus the establishment of the boundary, is carried out when the boundaries had not been determined previously. If such work has ever been done, then we speak of resuming (restoring) the boundaries rather than about delimitation. Importantly, the real estate area calculated after the delimitation may differ from the one shown in the Land and Building Records. The reason for such discrepancies is not always due to the change in the location of the boundaries, but it may be due to the applied level of the measuring and computational accuracy. When analysing the subject of the delimitation, it is worth mentioning that the subject of determining the boundaries of a real estate property may be one, several or all of the boundaries of the said property, as reported by Kwartnik-Pruc and Hanus [2014], among others. 
In turn, the resumption of boundary marks is a secondary procedure from the point of view of the surveyor's activities - that is to say, the marks in question had already been delineated in the land. The surveyor's job consists only in resuming (reconstruction) of their original position, and not defining them from scratch, as it happens during the delimitation procedure. On the cadastral map, the result of both procedures is similar. Boundary points are added along with a descriptive documentation about their location in the land, as well as their legal justification.

\section{Research material and methods}

In general, the following methods and research materials have been used in the present work:

- The descriptive analysis method for presenting the research problem.

- The method of comparative analysis in order to present the results of a thorough examination of the legal acts currently in effect in Poland, concerning the subject matter of this publication.

- The analysis of geodetic documentation, reporting the progression of the analysed geodetic tasks, made available by PODGiK in Kraków, or constituting the subject of the author's own professional work in the field.

\section{Results}

In the first stage, the process of delimitation of a real estate property was analysed based on the sources described above. It is a process that can be divided into two phases: the administrative phase and the judicial phase. The proceedings may be initiated either at the request of an interested party, or ex officio. The administrative phase begins at the moment of submitting the application for delimitation by an interested party. An application for delimitation of a real estate property may be submitted by a person who is [Jasińska-Cieślińska 2010]:

- the owner of the property,

- one of the co-owners of the property,

- an autonomous holder,

- a leaseholder.

- a tenant,

- a user.

The application to conduct the delimitation of the real estate property is submitted to the mayor, municipal administrator, or city governor. However, there are exceptions from this rule. Unlike other administrative procedures, delimitation proceedings are not initiated at the time of submitting the application at the applicant's request. This happens only when the authorized body issues a decision to initiate the delimitation proceedings. The date on which the delimitation proceedings are formally commenced 
is the day on which the last party received the notification of the decision on its initiation. If any of the parties have comments relating to the decision, they are entitled to refer the matter to the local government appeal board for examination of the case. If the decision was issued in accordance with the law, then the mayor, municipal administrator, or city governor is under the obligation to appoint an authorized land surveyor who will conduct the delimitation proceedings. At this point, the land surveyor starts work pertaining to the delimitation of the property and reports the geodetic task to the State Geodetic and Cartographic Documentation Centre (Państwowy Ośrodek Dokumentacji Geodezyjnej i Kartograficznej). Next, the designated surveyor is obliged to analyse all available documents from the State geodetic and cartographic resources, and to establish the legal status of the given real estate property (based on the data from Land and Mortgage Registers). Analysis of documents provided by the parties is also important at this stage, provided that these documents were developed as a result of geodetic measurements [Kwartnik-Pruc and Hanus 2014]. It should be added that the surveyor in this case may only be appointed ex officio. This is connected with the necessity of performing the function of an impartial negotiator in the discussed process. When making geodetic measurements in the land, the authorized surveyor is required to use geodetic control points. Regulation by the Minister of Internal Affairs and Administration on technical standards for performing land-survey situational and altitude measurements, and preparing and submitting results of these measurements to the state geodetic and cartographic resources $(\$ 12.1)$ directs that, if the surveyor uses the GNSS receiver in order to determine the coordinates of boundary markings or stabilization of new markings and determination of new boundary points, then he is under an obligation to perform a "control measurement on at least two points of the horizontal geodetic control network" in order to verify the correctness of determining the coordinates by the GNSS receiver applied. In addition, the points of the horizontal geodetic control network should not be removed by more than $5 \mathrm{~km}$ from the place where the measurements are conducted using the GNSS receiver. If while carrying out measurements, it becomes necessary to establish and stabilize the measuring network, then this should be done in such a way as to maintain its immutability over time. This means that the measuring network points should be stabilized or fixed in a permanent way. After all documents have been collected, including those from the poviat (district) Geodetic and Cartographic Documentation Centre, those received from interested parties, and those obtained from the field survey, the surveyor must make a selection. It is at this stage that the surveyor must analyse which documents are reliable, and reject those that do not constitute grounds for performing the delimitation of the real estate property. At this stage, the surveyor should compare the surveys in his possession against each other, and verify whether the measures or coordinates of the corresponding points in the land are compliant. Regarding the position of the stabilized (fixed) points in the land, linear deviations must not exceed $0.15 \mathrm{~m}$, while for non-stabilized (non-fixed) points, these must not exceed $0.25 \mathrm{~m}$. Before the boundary case hearing, the surveyor who carries out the property delimitation process must also be prepared to receive additional evidence during the hearing. The course of the 
boundary case hearing is defined in the Regulation by the Ministers of Internal Affairs and Administration and Agriculture and Food Economy of April 14, 1999 on the delimitation of real estate properties [Regulation 2011]. It lists the following stages of work: checking the attendance and determination of parties' identity, accepting proxies, field intelligence, determining the boundaries of the real estate property (possible settlement), stabilizing boundaries, and preparing documentation.

From the point of view of the subject matter of this article, the stage of determining the boundaries of the real estate property deserves particular attention. It can be carried out on the basis of: evidence received; consistent statements of parties to the proceedings; submission of a statement by one party, while the other party accepts this statement and does not formulate any reservations. The situation in which it is impossible to find any information about the real estate property is highly unlikely. This is because there should always exist a real estate cadastral map, at least in the analogue form. A situation in which equally important evidence is contradictory can occur - for instance, when there are two diiferent survey reports from other land surveying works. Geodetic practice shows that the same boundary could have been accepted in each report in different ways. The situation in which, on the basis of the collected documents, it is impossible to clearly establish the course of the boundaries may arise when the accuracy of measurements and calculations in documents constituting the evidence is lesser than the item being the object of the dispute. Kwartnik-Pruc and Hanus [2014] give an example of such a situation when discussing the dispute over the erroneous placement of the boundaries - for example, with an error of 1 metre, when in the documents collected by the surveyor, the boundary is established with the accuracy of $2.5 \mathrm{~m}$. Field intelligence should conclude with the presentation of a fixed boundary to the parties in the proceedings. Regardless of how the case concludes, whether the parties will accept the set boundary or whether they will question it, the surveyor's task is to stabilize or mark the boundary points, which were the subject of the determination or resumption procedure. These activities must be carried out in the presence of the parties. Otherwise, it may happen that the fixed boundary will become the subject of a dispute between property owners in the future, and the surveyor who had conducted such proceedings may be charged with negligence. Guidelines on how to stabilize boundary markings are set out in the Regulation on the delimitation of real estate property $\$ 17-18$ [Regulation 2011]. Furthermore, boundary marks should be placed in such locations that enable their being seen from one point to another. It should be remembered that the boundary sketch and the description of the course of the boundary are one, because the descriptive part of the boundary is drawn up on the basis of a sketch. It is worth mentioning that the boundary sketch is one of the most important documents, providing the foundation for asserting the course of the real estate boundary. A good solution, on the part of the surveyor, is to describe in detail the individual boundary sections, rather than the whole boundary. This kind of practice will facilitate describing the boundaries of the real estate property in a transparent and legible manner. An important element that is not specified in the regulation is the preparation of a supplementary map with the delimitation of the real estate property. The legislator did not specify what such a map should necessarily include. As a result of this state of 
affairs, it is often the case that supplementary maps with different content are required in particular Geodetic and Cartographic Documentation Centres. What is the most important is that no boundary point numbers should be missing from such a map.

One of the possible versions of the completion of a delimitation procedure is the conclusion of a settlement. Such settlement agreement can only be signed if the information gathered on the real estate property and its boundaries are insufficient. An additional condition is that the parties, who present the course of the boundary, state different opinions as to the location and course of that boundary. It is worth mentioning, however, that under the law a settlement that had been concluded by the parties in the presence of a surveyor has the power of a settlement made by the court. Due to the fact that the settlement thus concluded is not an administrative settlement, the mayor, municipal administrator, or city governor does not need to approve it. Thus the conclusion of the settlement by the parties ends the delimitation procedure of the real estate property. Pursuant to Article $105 \$ 1$ of the Code of Administrative Procedure, as a result of concluding a settlement, the competent authority issues decisions in which it discontinues the proceedings. The delimitation proceedings may be discontinued in whole or in part [Hycner and Połeć 2009]. If the documents that the surveyor possesses do not make it possible to fully determine the course of the boundary, and the statements of the parties are contradictory and they are not conducive to a compromise, the surveyor ends the procedure. In such a situation, the surveyor temporarily fixes the boundary marks in the land, optionally guided by appropriate criteria: either on the basis of the documents held, or on the basis of indications by each party to the proceedings, or on the basis of the latest recorded state of undisturbed possession. Moreover, the surveyor is under an obligation to draw up a boundary sketch, which illustrates each fixed option of the boundary of the real estate property. In this situation, the surveyor also draws up an opinion assessing all variants of the course of the boundary, based on the documents held and information received from the parties to the proceedings. In addition, the surveyor should present his own proposed version of the course of the boundary. After carrying out these activities, he passes the collected documents to the public administration body. The procedure for delimitation is discontinued, and the case is referred to the court. Within 14 days, the parties to the proceedings have the right to appeal against the cancellation of the proceedings. The appeal is directed to the higher instance body. We should add that the case is directed to the court at the time when the decision issued by the authority becomes final. The decision, which is issued by the court, is issued in a non-contentious manner.

The second case analysed in this publication concerns the resumption of boundary markings. It is a procedure that is carried out by an authorized surveyor at the request of interested parties. The surveyor's work in this respect is neither an administrative or judicial procedure. We should add that it is possible to carry out the procedure of resuming boundary marks only if there exist the documents that facilitate the determination of their original location. We should also mention that it is only possible to resume boundary marks if there is no dispute as to their location. The subject of the surveyor's work may be the resumption of the boundary marks, which were the subject of determination in two cases. The first case concerns the points, which had been determined according to 
the legal status of the property. The second case concerns the points that had been set for the purposes of the Land and Buildings Register. The boundary of the real estate property, which has been determined according to the legal status of the property, is somewhat binding. If the markings were resumed using this mode, then the property owners may, by law, demand that the matter be resolved - as reported by Łuczyński [2009]. As already mentioned, the resumption of boundary marks that had been previously disclosed in the Land and Buildings Register is regulated by the Geodetic and Cartographic Law [Ustawa 1989]. According to Article 39 of this Law, boundary marks may be subject to resumption if that can be done on the basis of the existing documents. Thus, boundary marks can be resumed if the previous boundary marks have been damaged or destroyed; if the boundary that is being resumed constitutes an indisputable boundary; if the resumed boundary marks had been settled in the past; if the resumed boundary marks have been stabilized in the past (otherwise we are talking about determining the boundary points disclosed in the EGiB, rather than the resumption of the boundary marks); or if there exists the documentation making it possible to determine their original location. In addition, there are a number of geodetic documents that contain numerical data on the location of boundary points. These include: boundary sketches and boundary protocols, settlement acts, measurement sketches and documents created as a result of geodetic works, for example, division of real estate, consolidation and exchange of land. If no documents mentioned above are available, when resuming boundary marks, it is possible to use maps: cadastral maps, land consolidation and exchange maps, land registry maps, or unit property maps. Boundary markings that had been stabilized in the land are protected. Any conscious breach or damage to a boundary mark is a crime, as described by Felcenloben [2013], among other authors.

The surveyor's work in the process of resuming the boundary marks starts when the interested party places an order (that is, commissions him to do so). As mentioned before, the resumption of boundary marks is not an administrative or judicial procedure; therefore it is not possible to make an application for the resumption of boundary marks. We should add that the process of resuming the marks does not lead to changes in the structure of the location of the real estate property in question, and hence to an update the Land and Buildings Register, as noted by Kwartnik-Pruc and Hanus [2014]. Field intelligence in the process of boundary marks resumption is aimed at finding all previously stabilized boundary marks. At this stage of the work, based on the collected documents, the surveyor may encounter three types of difficulties with finding the boundary marks. First of all, boundary marks that had previously been subject to stabilization in the land may have survived the test of time intact. Secondly, all or part of the boundary marks might have been damaged or even completely destroyed, or the collected documents might not allow a full discovery of the boundary marks. Thirdly, the data that is contained in the analysed file might not meet the applicable standards. The surveyor, having the necessary information on the location of the boundary marks, restores the boundary marks in the presence of the parties involved. The result of the surveyor's work in the field, as in the case of delimitation, should be the stabilization of the re-established boundary markings in the presence of the parties. The markings 
should be stabilized in a permanent manner so that it will be possible to maintain their fixed position in time. Furthermore, if necessary, the surveyor should make the indispensable field measurements. It is important that the stabilized signs in the field should be subject to a control measurement. If it turns out that the measuring network, which had been used for the initial determination of the boundary marks has since been damaged, the restoration of the markings should be made on the basis of topographic descriptions or the coordinates of the boundary points. Importantly, the coordinates of the boundary points must be subjected to a transformation, as noted by Felcenloben [2013] among other authors.

The diagram of determining the boundaries of a real estate property in relation to the discussed geodetic and legal processes is presented in Figure 1 and Table 1.

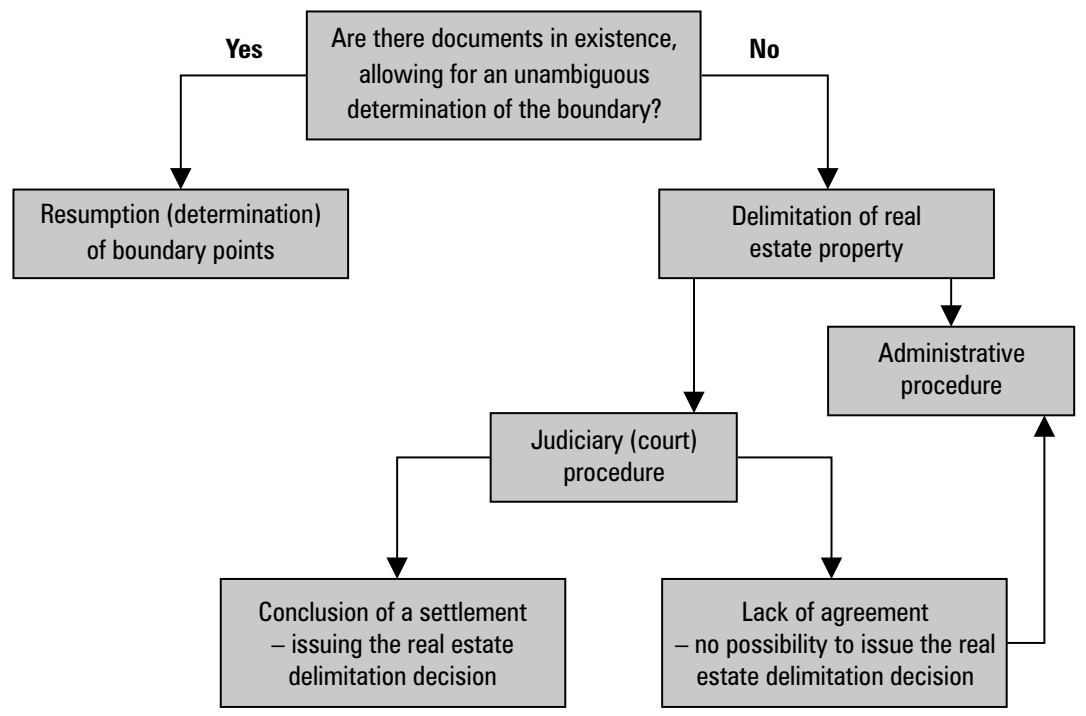

Source: Author's own elaboration

Fig. 1. Diagram showing the procedure of determining the boundaries of a real estate property

Table 1. Comparison between the processes of real estate property delimitation versus the resumption of boundary markings

\begin{tabular}{|l|l|l|}
\hline Aspect of comparison & \multicolumn{1}{|c|}{ Real estate property delimitation } & \multicolumn{1}{c|}{$\begin{array}{c}\text { Resumption of boundary } \\
\text { markings }\end{array}$} \\
\hline $\begin{array}{l}\text { Initiation of the } \\
\text { procedure }\end{array}$ & $\begin{array}{l}\text { Making an application to the mayor, } \\
\text { municipal administrator, or city } \\
\text { governor }\end{array}$ & $\begin{array}{l}\text { Commissioning the surveyor for } \\
\text { the works }\end{array}$ \\
\hline $\begin{array}{l}\text { Selection of the real } \\
\text { estate surveyor }\end{array}$ & $\begin{array}{l}\text { The mayor, municipal administrator, } \\
\text { or city governor }\end{array}$ & Interested party \\
\hline
\end{tabular}




\begin{tabular}{|c|c|c|}
\hline $\begin{array}{l}\text { Commencement of the } \\
\text { procedure }\end{array}$ & $\begin{array}{l}\text { From the moment of the mayor, } \\
\text { municipal administrator, or city } \\
\text { governor issue their decision }\end{array}$ & $\begin{array}{l}\text { From the moment of } \\
\text { commissioning the works of an } \\
\text { authorised surveyor }\end{array}$ \\
\hline $\begin{array}{l}\text { Commencement of } \\
\text { work }\end{array}$ & $\begin{array}{l}\text { Acquiring data from the Geodetic and } \\
\text { Cartographic Documentation Centre }\end{array}$ & $\begin{array}{l}\text { Acquiring data from the } \\
\text { Geodetic and Cartographic } \\
\text { Documentation Centre }\end{array}$ \\
\hline $\begin{array}{l}\text { When can the } \\
\text { procedure be applied? }\end{array}$ & $\begin{array}{l}\text { When no documents exist that } \\
\text { would allow for an unambiguous } \\
\text { determination of the boundary's course }\end{array}$ & $\begin{array}{l}\text { When the given boundary had } \\
\text { been previously subjected to } \\
\text { determination }\end{array}$ \\
\hline $\begin{array}{l}\text { Possible modes/forms } \\
\text { of the procedure }\end{array}$ & Administrative or judiciary & - \\
\hline $\begin{array}{l}\text { Subject of the } \\
\text { procedure/case }\end{array}$ & $\begin{array}{l}\text { Determining the course of the } \\
\text { boundary lines and fixing the } \\
\text { boundary markings in the land }\end{array}$ & $\begin{array}{l}\text { Fixing the boundary markings in } \\
\text { the land }\end{array}$ \\
\hline Reported area & $\begin{array}{l}\text { If necessary, boundary points of } \\
\text { neighbouring real estate properties } \\
\text { may be used }\end{array}$ & $\begin{array}{l}\text { The area of the single real estate } \\
\text { property }\end{array}$ \\
\hline $\begin{array}{l}\text { Notifications of the } \\
\text { parties, calling for their } \\
\text { presence in the land }\end{array}$ & By way of order & By way of notification \\
\hline Parties' participation & $\begin{array}{l}\text { Necessary for the completion of the } \\
\text { delimitation procedure (there is an } \\
\text { option to dispute) }\end{array}$ & $\begin{array}{l}\text { Not necessary for the resumption } \\
\text { of boundary marks }\end{array}$ \\
\hline $\begin{array}{l}\text { Course of the } \\
\text { boundary }\end{array}$ & Determined during the procedure & $\begin{array}{l}\text { The course of the boundary } \\
\text { remains unchanged }\end{array}$ \\
\hline $\begin{array}{l}\text { Possibility of dispute/ } \\
\text { disagreement }\end{array}$ & Yes & No \\
\hline Comments to the draft & $\begin{array}{l}\text { Presenting the surveyor with } \\
\text { a proposed course of the boundary }\end{array}$ & No \\
\hline $\begin{array}{l}\text { Result of the surveyor's } \\
\text { work }\end{array}$ & $\begin{array}{l}\text { Determining the course of the } \\
\text { boundary }\end{array}$ & $\begin{array}{l}\text { Fixing (stabilising) boundary } \\
\text { points in the land }\end{array}$ \\
\hline Updating the data & $\begin{array}{l}\text { Yes - determining the coordinates of } \\
\text { boundary points }\end{array}$ & $\begin{array}{l}\text { No - resumption of markings } \\
\text { does not lead to updating of } \\
\text { information in the data resources }\end{array}$ \\
\hline $\begin{array}{l}\text { Changing the area } \\
\text { size of the real estate } \\
\text { property }\end{array}$ & $\begin{array}{l}\text { Possible, arising from precise } \\
\text { calculations of point coordinates }\end{array}$ & $\begin{array}{l}\text { Impossible, as changes in } \\
\text { boundary point coordinates do } \\
\text { not occur }\end{array}$ \\
\hline $\begin{array}{l}\text { Level of difficulty in } \\
\text { conducting geodetic } \\
\text { work }\end{array}$ & $\begin{array}{l}\text { Very high - often there is lack of } \\
\text { documents that would indicate the } \\
\text { boundaries in an unambiguous way }\end{array}$ & $\begin{array}{l}\text { Low - the surveyor's work is } \\
\text { based on the documents which } \\
\text { fully determine the position of } \\
\text { boundary points }\end{array}$ \\
\hline $\begin{array}{l}\text { Conclusion of the } \\
\text { procedure }\end{array}$ & $\begin{array}{l}\text { Issuing an administrative decision } \\
\text { on the delimitation of a real } \\
\text { estate property; a court decision; } \\
\text { discontinuance of the proceedings } \\
\text { (conclusion of a settlement) }\end{array}$ & $\begin{array}{l}\text { When the survey report is } \\
\text { submitted to the Geodetic and } \\
\text { Cartographic Documentation } \\
\text { Centre }\end{array}$ \\
\hline
\end{tabular}




\section{Conclusions}

When analysing and comparing the two procedures - the delimitation and the resumption of boundary markings of a real estate property - first and foremost, it is necessary to pay attention to the scope and type of actions performed by the surveyor. Studies have shown that these seemingly similar geodetic-legal processes differ significantly in their details. In the case of the delimitation of a real estate property, the procedure begins not at the time of submitting the application, but at the time of issuing the decision. Thus, we see a significant difference at the very beginning, because in the resumption of the boundary marks, the surveyor starts work immediately after the given party contacts and commissions him to do so. Again, there is another difference: in the delimitation procedure, it is the head of a municipality, the mayor, or the city governor who decides which land surveyor will take care of this matter, whereas in the resumption of the boundary marks, it is the interested party that chooses the surveyor. At this point, it is worth noting that the delimitation of a real estate property may be subject either to administrative procedure or court proceedings, but when it comes to the resumption of the boundary markings, it is the surveyor's work - which does not add anything new to the geodetic resources, but only indicates to the interested party the extent of his ownership right to the land. It is also worth adding that in the delimitation proceedings, the boundary of a real estate property may be the subject of a dispute between the parties to the proceedings. In both cases, the surveyor submits the so-called report of surveying work to the Geodetic and Cartographic Documentation Centre. Also, he obtains all available documents for both procedures, however, in the delimitation procedure, some key documents concerning the course of the boundary are often missing, and what is important, no coordinates of all the property boundary points are found in any of the available resources. It is in this process that the surveyor - with the help of the parties and all possible documents - finds, determines and calculates the coordinates of the boundary points. Thereby, for the first time, he develops a full documentation of the given real estate boundary. Things are different in the process of resuming the boundary marks, because the surveyor possesses all the necessary documents, and his main task is to stabilize the boundary signs within the land. In both processes, during the field survey, the surveyors are accompanied by the parties - that is, the persons who hold the rights to the real estate property. In the resuming of boundary markings they merely become acquainted with the location where the boundary marks should be stabilized, whereas in the delimitation procedure they are active participants. They have the right to submit their comments and suggestions. Before that happens, however, the surveyor is obliged to call (in the delimitation of the real estate property) or to notify (in the resumption of the boundary marks) the parties, notifying them about the date of the field survey. As the process of real estate property delimitation may be either an administrative procedure or court proceedings, it may conclude either with issuing the decision by the head of a municipality, the mayor, or the city governor on the delimitation of the real estate property, or with a court 
judgment or discontinuance of the case (i.e. conclusion of a settlement). Regarding the resumption of boundary marks, the surveyor's work ends with the stabilization of points and the submission of the survey report to the Geodetic and Cartographic Documentation Centre. The measurement performed by the surveyor authorized to perform the process of real estate property delimitation is slightly different from other situational measurements carried out by the surveyor. The difference is due to the fact that during these activities, the surveyor measures the objects, which often are not found in any database of Land and Buildings Registers or geodetic records of the utilities network. This is because the real estate delimitation process itself can be based on the traces of the old property boundaries. Thanks to this, in addition to the boundary markings, the boundary of the property can be confirmed by the presence of such marks as: balk, turbot, ground bolts, steel rods, pipes, fences or fragments of fences, building corners, building walls, building remains, road edges, trees, and the boundary to which the land was used. The surveyor's work in terms of measuring boundary marks and traces goes beyond the scope of real estate property delimitation. In order for the information thus completed to fully reflect the nature of the case, often the neighbouring properties also need to be measured. It is important that the surveyor has information on how and with which measurement techniques the boundary marks had been stabilized. In the case of stabilization performed using, for example, orthogonal measurement, it is advisable for the surveyor to find and inspect all objects from the archived measurement line. An important personal trait of the surveyor is the ability to establish good rapport with people. It is in such cases that he must talk to the conflicted parties in such a way as to reach an agreement, leading to the settlement that would end the dispute over the boundary between them. What is crucial, he should maintain impartiality. To sum up, the processes of delimitating real estate property and resuming boundary marks differ significantly, not only in terms of the procedure and the degree of difficulty of the work conducted, but also in the possibility of complications occurring during the actions performed by the surveyor.

\section{References}

Felcenloben D. 2013. Granice nieruchomości i sposoby ich ustalania. LexisNexis, Polska.

Hycner R., Połeć T. 2009. Kryteria rozgraniczania nieruchomości w świetle przepisów oraz orzecznictwa Sądu Najwyższego i Naczelnego Sądu Administracyjnego. Acta Scientifica Academiae Ostroviensis, 32, 51-71.

Hycner R., Wiśniewska A. 2013. Przypadek sporu przy wznawianiu znaków granicznych nieruchomości. Acta Scientifica Academiae Ostroviensis, 1, 413-432.

Jasińska-Cieślińska O. 2010. Rozgraniczenie nieruchomości w postępowaniu administracyjnym, t. VI, PWSZ IPiA Studia Lubuskie, Sulechów.

Kwartnik-Pruc A., Hanus P. 2014. Geodezyjne aspekty rozgraniczeń i podziałów nieruchomości. Wydawnictwo AGH, Kraków.

Łuczyński R. 2009. Technologiczne i prawne aspekty wznawiania oraz ustalania przebiegu granic działek ewidencyjnych. Acta Scientiarum Polonorum, ser. Geodesia et Descriptio Terrarum, 8(3) 23-38. 


\title{
Legal acts:
}

Ustawa z dnia 23 kwietnia 1964 r. - Kodeks cywilny (Dz. U. z 2017 r., poz. 459, 933, 1132, z 2018 r. poz. 298).

Ustawa z dnia 6 lipca 1982 r. o księgach wieczystych i hipotece (Dz. U. z 2017 r., poz. 1007, z 2018 r. poz. 106, 431).

Ustawa z dnia 17 maja 1989 r. - Prawo geodezyjne i kartograficzne (Dz. U. z 2017 r., poz. 2101).

Ustawa z dnia 14 czerwca 1960 r. - Kodeks postępowania administracyjnego (Dz. U. z 2017 r., poz. 1257 ze zm.).

Rozporządzenie Ministra Administracji i Cyfryzacji z dnia 14 lutego 2012 r. w sprawie osnów geodezyjnych, grawimetrycznych i magnetycznych (Dz. U. z 2013 r., poz. 352).

Rozporządzenie Ministrów Spraw Wewnętrznych i Administracji oraz Rolnictwa i Gospodarki Żywnościowej z dnia 14 kwietnia 1999 r. w sprawie rozgraniczenia nieruchomości (Dz. U. z 1999 r. Nr 45, poz. 453).

Rozporządzenie Ministra Spraw Wewnętrznych i Administracji z dnia 9 listopada 2011 r. w sprawie standardów technicznych wykonywania geodezyjnych pomiarów sytuacyjnych i wysokościowych oraz opracowywania i przesyłania tych pomiarów do państwowego zasobu geodezyjnego i kartograficznego (Dz. U. z 2011 r. Nr 263, poz. 1572).

Rozporządzenie Rady Ministrów z dnia 15 października 2013 r. w sprawie państwowego systemu odniesień przestrzennych (Dz. U. z 2012 r., poz. 1247).

\author{
Dr inż. Paweł Kotlarz \\ Uniwersytet Rolniczy w Krakowie \\ Katedra Geodezji \\ 30-198 Kraków, ul. Balicka 253a \\ e-mail: p.kotlarz@urk.edu.pl \\ ORCID: https://orcid.org/0000-0001-6520-6462
}

